\title{
Unexpected rapid increase in bone mineral density by bisphosphonate therapy after multiple spinal fractures: a case report
}

\author{
Hidefumi Koiwai ${ }^{1}$, Mikio Kamimura ${ }^{2}$, Jun Takahashi ${ }^{3}$, Yukio Nakamura ${ }^{3,4^{*}}$ and Hiroyuki Kato ${ }^{3}$
}

\begin{abstract}
Background: Osteoporosis is a serious disease that causes bone fragility fractures and increases mortality. Bisphosphonates are the first-line drugs for osteoporosis. However, the gains in bone mineral density by use of bisphosphonates alone are limited.

Case presentation: We describe the clinical outcome of a Japanese woman with osteoporosis treated with bisphosphonates after multiple spinal fractures. After 3 years of treatment with the bisphosphonate alendronate, her lumbar bone mineral density and bilateral hip bone mineral density markedly increased by $61.9 \%$ and $32.5 \%$, respectively.

Conclusion: We considered that our patient's multiple fractures had caused a decrease in bone mineral density, which naturally improved with fracture healing to enhance the increase in bone mineral density with bisphosphonate treatment.
\end{abstract}

Keywords: Bone mineral density, Bisphosphonate, Osteoporosis, Spinal fracture

\section{Introduction}

Osteoporosis (OP) is a serious and widespread disease that predisposes patients to bone fragility fractures and increases mortality. Bisphosphonates (BPs) are the first-line drugs for OP treatment to increase bone mineral density (BMD) and prevent fractures $[1,2]$. However, the improvements in BMD by BPs alone are limited and gradually diminish after the first few years [3, 4]. Bone et al. observed that alendronate (ALN) provided increases of $13.8 \%$ in lumbar spine BMD (L-BMD) and $7.8 \%$ in total hip BMD (H-BMD) during 10 years [4]. Compared with BPs, teriparatide (TPTD) (parathyroid hormone 1-34) has stronger effects on L-BMD increase and inhibition of spinal fractures [5]. Therefore, TPTD may be preferential for patients with OP who have greatly diminished BMD and/or multiple bone fractures. We

\footnotetext{
*Correspondence: yxn14@aol.jp

${ }^{3}$ Department of Orthopaedic Surgery, Shinshu University School of Medicine, Asahi 3-1-1, Matsumoto 390-8621, Japan

${ }^{4}$ Department of Orthopedic Surgery, Showa-Inan General Hospital, Akaho

3230, Komagane 399-4117, Japan

Full list of author information is available at the end of the article
}

recently encountered a rare case of a patient with $\mathrm{OP}$ in whom BMD increased remarkably with BP treatment only.

\section{Case presentation}

Our patient was a 59 -year-old Japanese woman $49 \mathrm{~kg}$ in weight and $153.2 \mathrm{~cm}$ in height. Her chief complaint upon presentation was severe back pain. She reported having a total of five episodes of strong acute back pain in the previous year.

At the first visit, her L-BMD was $0.572 \mathrm{~g} / \mathrm{cm}^{2}(-4.5$ standard deviation $[\mathrm{SD}]$ ), and her H-BMD was $0.671 \mathrm{~g} /$ $\mathrm{cm}^{2}(-2.2 \mathrm{SD})$. Spinal radiographs showed five vertebral compression fractures. Bone turnover markers (BTMs) were highly increased (Table 1). Bone scintigraphy revealed high accumulation at one lumbar vertebra and one thoracic vertebra, with diffuse mild uptake throughout the entire spine.

She was diagnosed with OP in accordance with the revised criteria established by the Japanese Society for Bone and Mineral Research [6]. Because daily TPTD was not possible, owing to her living abroad, ALN $35 \mathrm{mg} /$ week was prescribed until her planned return. One 
Table 1 Changes in laboratory values during bisphosphonate therapy

\begin{tabular}{|c|c|c|c|c|}
\hline & Pretreatment & $\begin{array}{l}2 \\
\text { Months }\end{array}$ & $\begin{array}{l}4 \\
\text { Months }\end{array}$ & $\begin{array}{l}24 \\
\text { Months }\end{array}$ \\
\hline$\overline{A L P}(U / L)$ & 827 & 753 & 367 & 197 \\
\hline $\begin{array}{l}\text { NTX (nmol BCE } / \mathrm{mmol} \\
\mathrm{Cr} \text { ) }\end{array}$ & 313.5 & 9.8 & 31.3 & 13.9 \\
\hline $\mathrm{BAP}(\mu \mathrm{g} / \mathrm{L})$ & 90.5 & 94.7 & 32.3 & 12.7 \\
\hline
\end{tabular}

month later, her back pain was relieved, and she returned home. At 4 months of ALN, L-BMD and HBMD were greatly increased by $29.5 \%$ and $18.3 \%$, respectively (Figs. 1, 2). Hence, ALN treatment was continued.

The patient's BTMs began to decrease soon after therapy commencement (Table 1 ). During 2 years of treatment, the patient's urinary N-terminal telopeptide of type I collagen (NTX) decreased by $95.6 \%$ and serum bone alkaline phosphatase (BAP) fell by $85.6 \%$. At 3 years of ALN monotherapy, L-BMD and H-BMD were markedly increased by $61.9 \%$ and $32.5 \%$, respectively (Figs. 1, 2), which remained high over a treatment period of 6.5 years.

The present report was approved by the Institutional Ethics Committee at Shinshu University School of Medicine. The patient gave written informed consent for publication of her personal medical information prior to the start of treatment.

\section{Discussion}

After the first vertebral fracture, the risk of subsequent fractures increases greatly and may occur consecutively in a so-called vertebral fracture cascade [7]. The patient had experienced severe acute back pain five times throughout the year preceding treatment. Spinal radiographs confirmed five vertebral compression fractures, indicating the occurrence of a fracture cascade.

BTMs are normally increased during the fracturehealing process $[8,9]$. At the first visit, our patient's BTMs were extremely high (BAP, $90.5 \mu \mathrm{g} / \mathrm{L}$; NTX, 313.5 nmol bone collagen equivalents/mmol $\mathrm{Cr}$ ). However, they soon decreased after treatment commencement and were within reference values 2 years later. Thus, the BTMs might have been greatly increased by the vertebral fractures and then improved both from fracture healing and from ALN.

The effects of BPs on BMD are potent but limited. In a phase III study in Japan, the increases of L-BMD were $6.2 \%$ for ALN $5 \mathrm{mg} /$ day [10] and $4.9 \%$ for risedronate $2.5 \mathrm{mg} /$ day [11] at 48 weeks. L-BMD was also increased by $9.2 \%$ at 3 years of treatment with ALN $5 \mathrm{mg} /$ day [12]. In our patient's case, BMD increased remarkably with ALN alone during 3 years (L-BMD, 61.9\%; H-BMD, 32.5\%).This rate of increase is unexpected and supports

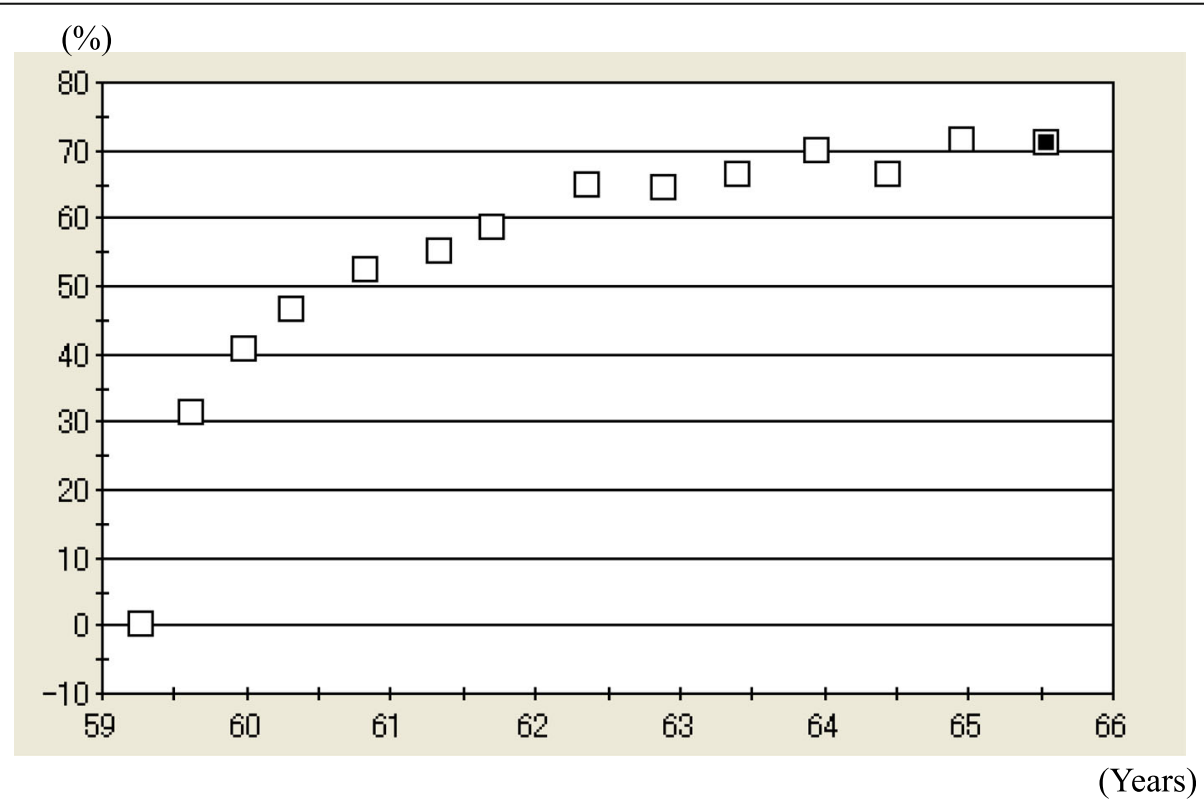

Fig. 1 Percentage changes in lumbar $1-4$ bone mineral density (L-BMD) from 59 to 66 years of age. L-BMD was $0.574 \mathrm{~g} / \mathrm{cm}^{2}$ (- $4.5 \mathrm{standard}$ deviation [SD]) prior to treatment, $0.824 \mathrm{~g} / \mathrm{cm}^{2}\left(-2.4 \mathrm{SD} ; 44.7 \%\right.$ increase) at 1 year, $0.877 \mathrm{~g} / \mathrm{cm}^{2}\left(-1.9 \mathrm{SD} ; 53.3 \%\right.$ increase) at 2 years, $0.926 \mathrm{~g} / \mathrm{cm}^{2}$ $\left(-1.5 \mathrm{SD} ; 61.9 \%\right.$ increase) at 3 years, and $0.957 \mathrm{~g} / \mathrm{cm}^{2}(-1.3 \mathrm{SD} ; 66.3 \%$ increase) at 6.5 years 


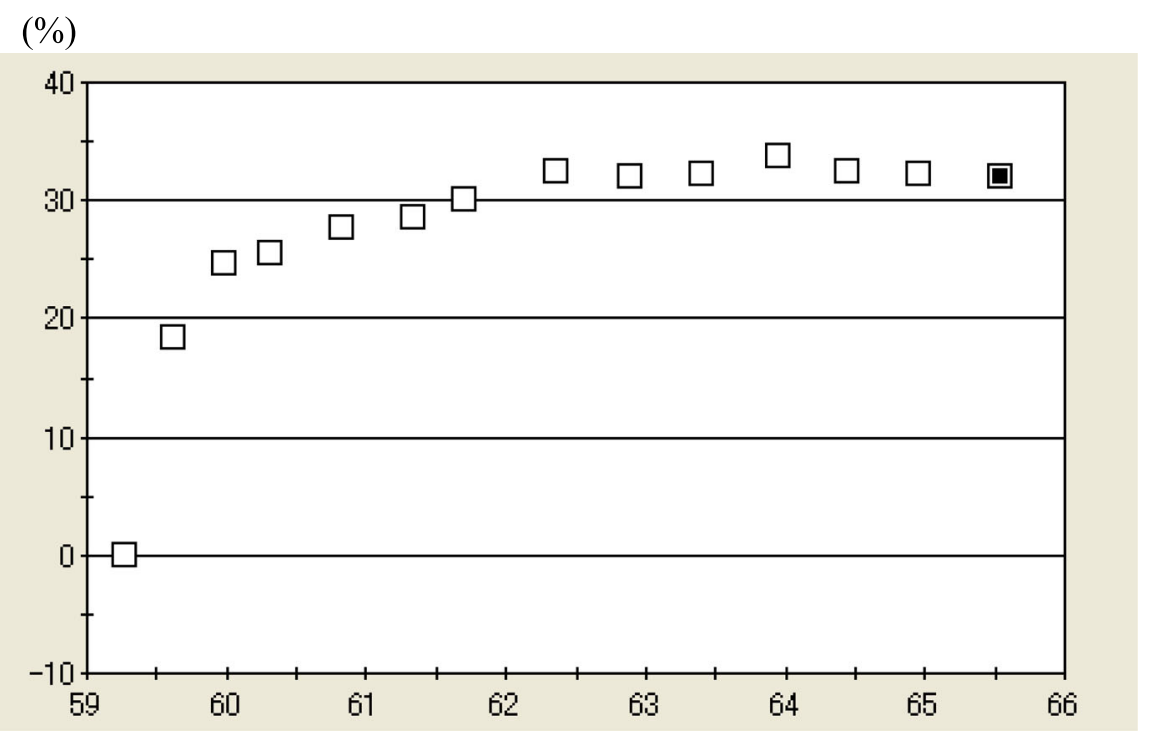

(Years)

Fig. 2 Percentage changes in bilateral total hip bone mineral density (H-BMD) from 59 to 66 years of age. H-BMD was $0.671 \mathrm{~g} / \mathrm{cm}^{2}(-2.2$ standard deviation [SD]) prior to treatment, $0.842 \mathrm{~g} / \mathrm{cm}^{2}\left(-0.8 \mathrm{SD} ; 25.5 \%\right.$ increase) at 1 year, $0.862 \mathrm{~g} / \mathrm{cm}^{2}(-0.6 \mathrm{SD} ; 28.5 \%$ increase) at 2 years, $0.889 \mathrm{~g} / \mathrm{cm}^{2}\left(-0.4\right.$ SD; $32.5 \%$ increase) at 3 years, and $0.885 \mathrm{~g} / \mathrm{cm}^{2}(-0.4 \mathrm{SD} ; 31.9 \%$ increase) at 6.5 years

an additional mechanism of BMD improvement, such as the natural healing of the fracture cascade.

We previously reported two cases of pregnancy- and lactation-associated OP with multiple vertebral fractures [13]. In both patients, BMD gains with vitamins $\mathrm{D}$ and $\mathrm{K}$ treatment were impressive at $36.1 \%$ at 4 years in the first patient and $26.3 \%$ at 3 years in the second. In a recently encountered patient with anorexia nervosa, BTMs were highly increased by multiple vertebral fractures [14]. Treatment using a vitamin $\mathrm{D}$ analogue alone achieved remarkable L-BMD and H-BMD gains of $70.7 \%$ and $41.4 \%$, respectively, at 8 months, although BMD improvement by vitamin $\mathrm{D}$ and/or $\mathrm{K}$ is usually very small. Similarly, in the present case, BMD increased markedly with BP monotherapy, with L-BMD gains of $29.5 \%$ at 4 months and $48.9 \%$ at 1 year. Results such as these seem possible only with simultaneous healing of fractures.

The common point in the above reports is the benefit of OP treatment after multiple fractures. On the basis of our findings, it was considered that multiple fractures might have caused decreases in BMD, which might be naturally improved by fracture healing to enhance the effects of OP treatment.

\section{Limitations}

The lack of serum $25(\mathrm{OH}) \mathrm{D}_{3}$ data is a major limitation of this study. We have previously reported that 4 months of BP therapy significantly decreased $25(\mathrm{OH}) \mathrm{D}_{3}$ and that 3-year BP therapy without vitamin $\mathrm{D}$ supplementation significantly increased $25(\mathrm{OH}) \mathrm{D}_{3}[15,16]$. However, in our patient's case, BMD rapidly increased; thus, we speculated that $25(\mathrm{OH}) \mathrm{D}_{3}$ levels might not have had an obvious influence on the results in this study. Another limitation of the present study includes its retrospective design. Nonetheless, our case report provides evidence of a good response in BMD after BP treatment in a patient with multiple fractures.

\section{Conclusions}

We report a rare case, that of a 59-year-old woman with OP in whom BMD increased remarkably with BP treatment only. This case report reveals that multiple fractures might have caused decreases in BMD, which were naturally improved by fracture healing to enhance the effects of OP treatment.

\section{Acknowledgements}

Not applicable.

\section{Authors' contributions}

YN and MK directed and designed this study. HK, MK, and YN wrote the main text. JT and HK gave suggestions on the study. All authors read and approved the final manuscript.

\section{Funding}

Not applicable.

\section{Consent for publication}

Written informed consent was obtained from the patient for publication of this case report and any accompanying images. A copy of the written consent is available for review by the Editor-in-Chief of this journal.

Competing interests

The authors declare that they have no competing interests. 


\section{Author details}

'Koiwai Orthopedic Clinic, Mikageshinden 1585-4, Komoro 384-0091, Japan. ${ }^{2}$ Center of Osteoporosis and Spinal Disorders, Kamimura Orthopedic Clinic, Kotobuki 595-17, Matsumoto 399-0021, Japan. ${ }^{3}$ Department of Orthopaedic Surgery, Shinshu University School of Medicine, Asahi 3-1-1, Matsumoto 390-8621, Japan. ${ }^{4}$ Department of Orthopedic Surgery, Showa-Inan General Hospital, Akaho 3230, Komagane 399-4117, Japan.

Received: 22 May 2019 Accepted: 5 August 2019

Published online: 13 September 2019

\section{References}

1. Lyles KW, Colón-Emeric CS, Magaziner JS, et al. HORIZON Recurrent Fracture Trial. Zoledronic acid and clinical fractures and mortality after hip fracture. N Engl J Med. 2007;357:1799-1809.

2. Beaupre LA, Morrish DW, Hanley DA, et al. Oral bisphosphonates are associated with reduced mortality after hip fracture. Osteoporos Int. 2011;22:983-91.

3. Kamimura M, Nalkamura Y, Ikegami S, Uchiyama S, Kato H, Taguchi A Significant improvement of bone mineral density and bone turnover markers by denosumab therapy in bisphosphonate-unresponsive patients. Osteoporosis Int. 2017;28(2):559-66.

4. Bone HG, Hosking D, Devogelaer JP, Tucci JR, Emkey RD, Tonino RP, Rodriguez-Portales JA, Downs RW, Gupta J, Santora AC, Liberman UA. Alendronate phase III osteoporosis treatment study group. Ten years' experience with alendronate for osteoporosis in postmenopausal women. $\mathrm{N}$ Engl J Med. 2004:350:1189-99.

5. Neer RM, Arnaud CD, Zanchetta JR, Prince R, Gaich GA, Reginster JY, Hodsman $A B$, Eriksen EF, Ish-Shalom S, Genant HK, Wang O, Mitlak BH. Effect of parathyroid hormone (1-34) on fractures and bone mineral density in postmenopausal women with osteoporosis. N Engl J Med. 2001;344:1434-41.

6. Orimo H, Nakamura T, Hosoi T, Iki M, Uenishi K, Endo N, Ohta H, Shiraki M, Sugimoto T, Suzuki T, Soen S, Nishizawa Y, Hagino H, Fukunaga M, Fujiwara S. Japanese 2011 guidelines for prevention and treatment of osteoporosis: executive summary. Arch Osteoporos. 2012;7:3-20.

7. Briggs AM, Greig AM, Wark JD. The vertebral fracture cascade in osteoporosis: a review of aetiopathogenesis. Osteoporos Int. 2007;18:575-84.

8. Nakagawa $\mathrm{H}$, Kamimura M, Takahara $\mathrm{K}$, Hashidate $\mathrm{H}$, Kawaguchi $\mathrm{A}$ Uchiyama S, Miyasaka T. Changes in total alkaline phosphatase level after hip fracture: comparison between femoral neck and trochanter fracture. J Orthop Sci. 2006;11:135-59.

9. Takahara K, Kamimura M, Nakagawa H, Uchiyama S. Changes in biochemical markers of bone in patients with insufficiency fractures. J Bone Miner Metab. 2004:22:618-25.

10. Shiraki M, Kushida K, Fukunaga M, Kishimoto H, Taga M, Nakamura T, Kaneda K, Minaguchi H, Inoue T, Morii H, Tomita A, Yamamoto K, Nagata Y, Nakashima M, Orimo H, Alendronate Phase III Osteoporosis Treatment Research Group. A double-masked multicenter comparative study between alendronate and alfacalcidol in Japanese patients with osteoporosis. Osteoporos Int. 1999;10:183-92.

11. Fukunaga M, Kushida K, Kishimoto $H$, Shiraki M, Taketani $Y$, Minaguchi $H$ Inoue T, Morita R, Morii H, Yamamoto K, Ohashi Y, Orimo H. Risedronate Phase III Research Group. A comparison of the effect of risedronate and etidronate on lumbar bone mineral density in Japanese patients with osteoporosis: a randomized controlled trial. Osteoporos Int. 2002;13:971-9.

12. Kushida K, Shiraki M, Nakamura T, Kishimoto H, Morii H, Yamamoto K, Kaneda K, Fukunaga M, Inoue T, Nakashima M, Orimo H. Alendronate reduced vertebral fracture risk in postmenopausal Japanese women with osteoporosis: a 3-year follow-up study. J Bone Miner Metab. 2004:22:462-8.

13. Nakamura Y, Kamimura M, Ikegami S, Mukaiyama K, Komatsu M, Uchiyama $\mathrm{S}$, Kato $\mathrm{H}$. A case series of pregnancy- and lactation-associated osteoporosis and a review of the literature. Ther Clin Risk Manag. 2015;11:1361-5.

14. Nakamura $\mathrm{Y}$, Kamimura $\mathrm{M}$, Koiwai $\mathrm{H}$, Kato $\mathrm{H}$. Adequate nutrition status important for bone mineral density improvement in a patient with anorexia nervosa. Ther Clin Risk Manag 2018;14:945-948.

15. Kamimura M, Uchiyama S, Nakamura Y, Mukaiyama K, Ikegami S, Kato H. Short-term bisphosphonate treatment reduced the $25(\mathrm{OH})$ vitamin $\mathrm{D}_{3}$ level, and changed the values of parathyroid hormone, pentosidine, and bone metabolic markers by short-term bisphosphonate treatment. Ther Clin Risk Manag. 2017:13:161-8.
16. Nakamura Y, Uchiyama S, Kamimura M, Ikegami S, Komatsu M, Kato H. Increased serum 25(OH)D3 levels in post-menopausal Japanese women with osteoporosis after 3-year bisphosphonate treatment. Tohoku J Exp Med. 2017;242:241-6.

\section{Publisher's Note}

Springer Nature remains neutral with regard to jurisdictional claims in published maps and institutional affiliations.
Ready to submit your research? Choose BMC and benefit from:

- fast, convenient online submission

- thorough peer review by experienced researchers in your field

- rapid publication on acceptance

- support for research data, including large and complex data types

- gold Open Access which fosters wider collaboration and increased citations

- maximum visibility for your research: over $100 \mathrm{M}$ website views per year

At BMC, research is always in progress.

Learn more biomedcentral.com/submissions 